ASIA AND INTERNATIONAL ORGANIZATIONS 
M.C.W. Pinto - 9789047408253

Downloaded from Brill.com๑4/26/2023 $09: 19: 49 \mathrm{AM}$ via free access 


\section{ASIAN-AFRICAN LEGAL CONSULTATIVE ORGANIZATION BI-ANNUAL SURVEY OF ACTIVITIES 2000-2001}

including the work of its Fortieth Session held at New Delhi, 20-24 June 2001 .

M.C.W. Pinto*

Note: The Asian-African Legal Consultative Committee (now: Organization) was established on 15 November 1956 to facilitate the exchange of views and information on legal matters of common concern to its Members. Its regular Sessions are convened annually, alternately in Asia and Africa. A Session generally takes place in the first half of a calendar year, and is known by the name of the city in which it is held. Consideration of a topic commenced at one Session may continue at subsequent Sessions, as well as inter-sessionally through seminars or expert group meetings, which retain their association with the originating Session. Reports on interSessional activities may be discussed at the following Session.

By a decision adopted at its Special Session in New Delhi on 14 October 1992 (Res. SS 1997/1), the Organization's permanent headquarters were established in New Delhi.

Member States are represented at Sessions by high level delegations, which may include Chief Justices, Judges, Cabinet Ministers, Attorneys-General, and senior public officials. Sessions are routinely attended by observers from non-Member States, and inter-governmental and non-governmental organizations. The Organization maintains working relationships with the United Nations and its Specialized Agencies and Commissions, as well as with other international organizations, including the International Atomic Energy Agency, UNIDROIT, the Hague Conference on Private International Law, the Commonwealth Secretariat, the Organization of African Unity and the League of Arab States.

The present survey covers the focus of the work of the Organization's Fortieth Session, held at New Delhi, 20-24 June 2001, while containing references also to activities associated with Sessions which were covered in earlier volumes of this Yearbook.

\footnotetext{
${ }^{*}$ Of the Editorial Board.

Asian Yearbook of International Law, Volume 10 (B.S. Chimni et al., eds.)

(C) 2005 Koninklijke Brill NV. Printed in The Netherlands, pp. 293-329.
} 
Information on the activities of AALCO may be obtained from:

The AALCO Secretariat, E-66, Vasant Marg., Vasant Vihar, New Delhi 110057, India, E-mail: aalcc@del3.vsnl.net.in

\section{MEMBERSHIP AND ORGANIZATION}

There were forty-four Members of the Organization at the time of its Fortieth Session, held at New Delhi, India, from 20-24 June 2001: Bahrain, Bangladesh, China, Cyprus, Egypt, Gambia, Ghana, India, Indonesia, Iran, Iraq, Japan, Jordan, Kenya, Democratic People's Republic of Korea, Republic of Korea, Kuwait, Lebanon, Libya, Malaysia, Mauritius, Mongolia, Myanmar, Nepal, Nigeria, Oman, Pakistan, Palestine, Philippines, Qatar, Saudi Arabia, Senegal, Sierra Leone, Singapore, Somalia, Sri Lanka, Sudan, Syria, Tanzania, Thailand, Turkey, Uganda, United Arab Emirates, and Yemen. Botswana is an Associate Member.

\section{INTER-SESSIONAL MEETINGS AND OTHER ACTIVITIES}

A Meeting of Legal Advisers of AALCO Member States convened at New York on 26 October 2000, presided over by Ambassador Aboul Geit, Permanent Representative of the Arab Republic of Egypt to the United Nations. The meeting focused on the Jurisdictional Immunities of States and their Property, and was attended inter alia by Professor Gerhard Hafner, Chairman of the UN Sixth Committee's Working Group on that topic (Report, pages 4-7).

A Seminar on International Humanitarian Law was held at New Delhi on 17 November 2000 on the occasion of AALCO's 44th Constitution Day, sponsored jointly with the International Committee of the Red Cross, and presided over by H.E. Gehad Madi, Ambassador of the Arab Republic of Egypt to India (Report, pages 8-9).

An open-ended Working Group to finalize the revised consolidated text of AALCO's Bangkok Principles on the Status and Treatment of Refugees met in New Delhi, 26-27 February 2001. Dr. Mrs. Neeru Chadha, Legal Officer, Ministry of External Affairs of India, was appointed Rapporteur.

The work of AALCO's Regional Arbitration Centres established at Cairo, Kuala Lumpur, Lagos and Tehran is referred to at pages 14-17 of the Secretariat's Report of the Fortieth Session ("Report").

The Organization's Data Collection Unit, with a broader range of functions, and re-named Centre for Research and Training is funded by the Republic of Korea and has available a range of information on the economic laws and regulations of Member States. See Report, pages 12-14.

\section{OFFICERS OF THE FORTIETH (NEW DELHI) SESSION}

The Fortieth Session of the Organization elected Dr. P. Sreenivasa Rao as its President. Joint Secretary and Legal Adviser to the Ministry of External Affairs, India, Chief Bola Ige San, Attorney General and Minister of Justice, Nigeria, was elected Vice-President of the Session. Ms. Nelum Mayadunne, Assistant Legal Adviser to the Ministry of Foreign Affairs, Sri Lanka, was appointed Rapporteur of a Special 
Meeting on Some Legal Aspects of Migration held on 22 June 2001 (Report, pages 598-645).

Organization of the Session was the responsibility of the Secretary-General of the Organization, Mr. Tang Chengyuan, who was assisted by Deputy SecretariesGeneral Dr. Wafik Zaher Kamil, Mr. Mohammed Reza Dabiri and Mr. Ryo Takagi, as well as by Assistant Secretaries-General and members of the Secretariat.

\section{ADMINISTRATIVE MATTERS}

By its resolution RES/40/ORG.3 dated 24 June 2001, adopted at its Fortieth Session, the Asian-African Legal Consultative Committee (AALCC) decided to change its name to Asian-African Legal Consultative Organization (AALCO).

At that Session Dr. Wafik Zaher Kamil (Egypt) was appointed Secretary-General of the Organization. Dr. Kamil took office in May 2001, upon retirement of Mr. Tang Chengyuan (China).

\section{SUBJECTS DEALT WITH BY THE ORGANIZATION}

The Organization considered and adopted decisions on the subjects listed below, the order of their discussion being determined at the commencement of the Session. The references next to each subject are to the pages of the Report of the Fortieth Session issued by the Secretariat** The Report on each Session will, from 2002, be contained in a volume entitled Yearbook of the Asian-African Legal Consultative Organization.

I. Questions under consideration by the International Law Commission (Report, pages 169-304)

The Secretariat's report on the work of the Commission at its Fifty-second Session (2000) focussed on the Commission's work on six topics: State responsibility; International liability for injurious consequences arising out of acts not prohibited by international law; Reservations to treaties; Diplomatic protection; Unilateral acts of States; and Jurisdictional immunities of States and their property. Of particular interest from an Asian perspective are (1) Jurisdictional immunities of States and their property, a topic of the International Law Commission which, on the initiative of Japan at AALCO's the Cairo Session, was placed on the Organization's own agenda (Report, pages 305-358); and (2) International liability for injurious consequences arising out of acts not prohibited by international law, a topic on which the Commission's Special Rapporteur is (Report, pages 280-304) Dr. P. Sreenivasa Rao of India (Report, pages 280-304).

\section{Matters referred to the Organization by Member States}

1. Law of the Sea (Report, pages 23-64)

The Committee reviewed the work of the institutions created for giving effect to the provisions of the 1982 UN Convention on the Law of the Sea, expressing satisfaction at the adoption by the Council of the International Seabed Authority on 13 July 2000, of the Regulations on Prospecting and Exploration for Polymetallic Nodules in the Area, as well as at the working of the International Tribunal for the 
Law of the Sea, and related dispute settlement mechanisms. Members welcomed the UN General Assembly's establishment (resolution 54/33 of 24 November 1999) of an open-ended informal consultative process (UNCIPO), with a mandate (i) to study developments in ocean affairs consistent with the legal framework provided by the UN Convention and the goals of Chapter 17 of Agenda 21, (ii) against the background of overall developments of all relevant ocean issues, to identify particular issues to be considered by the General Assembly; and (iii) to place emphasis on areas where co-ordination and co-operation at the inter-governmental and the inter-agency level were needed.

2. Status and treatment of Refugees (Report, pages 113-168)

The Organization completed its work on a consolidated text of the Revised Bangkok Principles (for the original text see Asian YIL, Vol 7 (1997), pages 381-7) taking into account Member States' comments. The Revised Consolidated text of the Bangkok Principles on the Status and Treatment of Refugees adopted by the Organization on 24 June 2001 is reproduced at A below.

3. Deportation of Palestinians and other Israeli practices among them the massive immigration and settlement of Jews in occupied territories in violation of international law, particularly the Fourth Geneva Convention of 1949 (Report, pages 445-507)

A Secretariat summary of international action on the subject (Report, pages 466507) covers an Asian Meeting on the Question of Palestine 1-3 March 2000, and the Hanoi Declaration adopted there; the Vatican/PLO Agreement on Church Rights in the Holy Land and Jerusalem 15 February 2000; the work of the UN General Assembly's Committee on the Exercise of Inalienable Rights of the Palestinian People; the South Summit meeting, Havana, 10-14 April 2000 and the XIII Ministerial meeting of the Non-aligned Nations, Cartagena, 8-9 April 2000; the International Meeting in Support of Peaceful Settlement of the Question of Palestine, 23-4 May 2000; the annual Co-ordination Meeting of the Foreign Ministers of the Organization of the Islamic Conference (OIC), New York, 18 September 2000; the 10th Emergency Special Session on Illegal Israeli Actions, New York, 18 October 2000; the Extraordinary Arab Summit Conference, Cairo, 21-2 October 2000; UN Security Council consideration of international protection for Palestinian civilians, 31 October 2000; the Sharm El-Sheikh Understanding Fact-finding Committee, 7 November 2000; the Report of the High Commissioner for Human Rights on her visit to occupied Palestinian Territory, 8-16 November 2000; Peace Proposals by President Clinton, 23 December 2000; and the Arab League Foreign Ministers' Meeting, Cairo, 3 January 2001.

\section{Legal protection of Migrant Workers (Report, pages 593-689)}

The item was discussed extensively at a Special Meeting on Some Legal Aspects of Migration, held on 22 June 2001 during the Fortieth Session of the Organization, with collaboration and support from the International Organization for Migration, and other international organizations. The Report contains a summary of the dis- 
cussion at the Special Meeting and the resolution adopted by the Organization (pages 598-645), as well as a Secretariat study on the topic (pages 646-689).

\section{Extra-territorial application of national legislation: sanctions imposed against} third parties (Report, pages 65-112)

Members re-affirmed views expressed at the Organization's 36th, 37th, 38th and 39th Sessions that the extra-territorial imposition of national laws violated State sovereignty and interfered with the legitimate economic interests of States. A Secretariat study on the subject and the Secretariat's report on discussion of related issues at the 55th Session of the United Nations General Assembly, are at pages 78-112.

6. Jurisdictional immunities of States and their property (Report, pages 305-358) Referred to the Committee at its Cairo Session (2000) by the Delegation of Japan, consideration of this topic by the Committee takes account of the work of the International Law Commission, and discussion of it at meetings of the Sixth Committee of the UN General Assembly. With a view to collating the views of AALCO's Members States, the Secretary-General by his letter dated 3 July 2000, invited them to transmit to it national legislation, court decisions and other relevant materials on the topic. By January 2001, four countries had done so. Their responses are reproduced at $\mathbf{B}$ below.

7. International terrorism (Report, pages 508-552)

Referred to the Committee by the Government of India, the topic was placed on the agenda of the Fortieth Session for the first time. The Explanatory Note provided by India, and a preliminary study by the Secretariat, are reproduced at $\mathbf{C}$ below.

8. Establishing co-operation against trafficking in women and children (Report, pages 553-592)

Referred to the Committee by the Government of Indonesia, the topic was placed on the agenda of the Fortieth Session for the first time. The Explanatory Note provided by Indonesia, and a preliminary study by the Secretariat, are reproduced at $\mathbf{D}$ below.

\section{Matters of common concern having legal implications}

1. United Nations Diplomatic Conference of Plenipotentiaries on the establishment of an International Criminal Court (Rome, 15 June-17 July 1998): the work of the Preparatory Commission for an International Criminal Court (Report, pages 359-407)

The Secretariat's report of the work of the Preparatory Commission covers the work of the Commission's Sixth Session (27 November-8 December 2000). Notes on the initiatives of AALCO's Members in regard to signature and ratification of the Rome Statute are at pages 390-407. 
2. United Nations Conference on Environment and Development (Report, pages 409-444)

The Report contains the Secretariat's review of the work of the Conference of the Parties to the UN Convention on Climate Change at its first session (13-25 November 2000). The Report also covers the work of the fifth session of the Conference of the Parties to the UN Convention on Biological Diversity (1998), 15-26 May 2000; and of the fourth session of the Conference of the Parties to the Convention to Combat Desertification, 11-22 December 2000.

IV International Trade Law Matters (Report, pages 690-815)

The Secretariat continued its regular review of the work of international organizations in the field of international trade law. The review covers the work of the United Nations Commission on International Trade Law (UNCITRAL), the United Nations Conference on Trade and Development (UNCTAD) and its Commissions, and the United Nations Industrial Development Organization (UNIDO); as well as of the International Institute for the Unification of Private Law UNIDROIT), the Hague Conference on Private International Law, and the World Trade Organization. A Secretariat study entitled "WTO as a Framework Agreement and Code of Conduct for World Trade" is at pages 787-815.

\section{Article VII Voluntary Repatriation}

1. The essentially voluntary character of repatriation shall be respected in all cases and no refugee shall be repatriated against his will.

2. The country of asylum, in collaboration with the country of origin, shall make adequate arrangements for the safe return of refugees who request repatriation.

3. The country of origin shall provide all necessary documents to expedite their return on receiving back refugees, facilitate their resettlement and grant them the full rights and privileges of nationals of the country, and subject them to the same obligations.

4. Refugees who voluntarily return to their country shall in no way be penalized for having left it or for any of the reasons giving rise to refugee situations. Whenever necessary, an appeal shall be made through national information media and through the relevant universal and regional organizations inviting refugees to return home without risk and to take up a normal and peaceful life without fear of being disturbed and punished, and that the text of such appeal should be given to refugees and clearly explained to them by their country of asylum.

5. Refugees who freely decide to return to their homeland, as a result of such assurances or on their own initiative, shall be given every possible assistance by the 
country of asylum, the country of origin, the country of transit, voluntary agencies and international and intergovernmental organizations to facilitate their return.

\section{Article VIII ${ }^{1}$ International Cooperation on Comprehensive Solutions ${ }^{2}$}

1. Voluntary repatriation, local settlement or third country resettlement, that is, the traditional solutions, all remain viable and important responses to refugee situations, even while voluntary repatriation is the pre-eminent solution. To this effect, States may undertake, with the help of inter-governmental and non-governmental organizations, development measures which would underpin and broaden the acceptance of the three traditional durable solutions.

2. States shall promote comprehensive approaches, including a mix of solutions involving all concerned States and relevant international organizations in the search for and implementation of durable solutions to refugee problems.

3. The issue of root causes is crucial for solutions, and international efforts should also be directed to addressing the causes of refugee movements and the creation of the political, economic, social, humanitarian and environmental conditions conducive to repatriation.

\section{Article IX Right to Compensation}

1. A refugee shall have the right to receive compensation from the State or the Country which he left or to which he was unable to return. ${ }^{3}$

\footnotetext{
1 At the Open-ended Working Group Meeting held in New Delhi 26-27 February 2001, the delegate of India maintained her Government's position to place reservation on this Article. "The Government of India expresses its reservation on including a separate Article VIII on "International cooperation and comprehensive solutions". It wants the emphasis to remain on 'voluntary repatriation'. The other solutions like 'local settlement' or 'third country resettlement', according to it, would have to be considered carefully in each case, given their political, economic or security implications, particularly in situations of mass influx. In this connection, a distinction needs to be maintained between the 'individual refugees' and 'situations of mass influx', as well as between 'convention refugees' and 'economic migrants'. Further, the implementation of these solutions and treatment of refugees is linked to the available resources and capacity of each State."

${ }^{2}$ Proposition of the AALCC Secretariat and the UNHCR to change the earlier title "Other solutions" to "International Cooperation on Comprehensive Solutions", which met with the approval of the Working Group.

${ }^{3}$ In view of the financial and economic implications reservations were expressed at the Manila and Tehran Meetings on the right of refugees to receive compensation. Reservations to paragraph 1 were expressed by the Governments of Sudan, Pakistan, Turkey, Jordan, and Tanzania. The Government of Tanzania also proposed a reference to some mechanism accessible by all parties in order to deal with compensation issues. During the Open-ended Working Group Meeting held
} 
2. The compensation referred to in paragraph 1 shall be for such loss as bodily injury, deprivation of personal liberty in denial of human rights, death of the refugee or of the person whose dependant the refugee was, and destruction of or damage to property and assets, caused by the authority of the State or Country, public officials or mob violence.

3. Where such person does not desire to return, he shall be entitled to prompt and full compensation by the Government or the authorities in control of such place of habitual residence as determined, in the absence of agreement by the parties concerned, by an international body designated or constituted for the purpose by the Secretary General of the United Nations at the request of either party.

4. If the status of such a person is disputed by the Government or the authorities in control of such place of habitual residence, or if any other dispute arises, such matter shall also be determined, in the absence of agreement by the parties concerned, by an international body designated or constituted as specified in paragraph (3) above.

\section{Article X Burden Sharing}

1. The refugee phenomenon continues to be a matter of global concern and needs the support of the international community as a whole for its solution and as such the principle of burden sharing should be viewed in that context.

2. The principle of international solidarity and burden sharing needs to be applied progressively to facilitate the process of durable solutions for refugees, whether within or outside a particular region, keeping in perspective that durable solutions in certain situations may need to be found by allowing access to refugees in countries outside the region, due to political, social and economic considerations.

3. The principle of international solidarity and burden sharing should be seen as applying to all aspects of the refugee situation, including the development and strengthening of the standards of treatment of refugees, support to States in protecting and assisting refugees, the provision of durable solutions and the support of international bodies with responsibilities for the protection and assistance of refugees.

4. International solidarity and cooperation in burden sharing should be manifested whenever necessary, through effective concrete measures where the major share shall be borne by developed countries. ${ }^{4}$

on 26-27 February 2001, upon a request from the Chairman the delegate of Tanzania promised to send a concrete draft on his suggestion to be studied by the Secretariat.

${ }^{4}$ During the Open-ended Working Group Meeting held in New Delhi on 26-27 February 2001, at the suggestion of the delegation of Pakistan the phrase "where [the] major share be borne by developed countries" was included. 
5. In all circumstances, the respect for fundamental humanitarian principles is an obligation for all members of the international community. Giving practical effect to the principle of international solidarity and burden sharing considerably facilitates States' fulfilment of their responsibilities in this regard.

\section{Article XI \\ Obligations}

A refugee shall not engage in subversive activities endangering the national security of the country of refuge or any other country ${ }^{5}$ or in activities inconsistent with or against the principles and purposes of the United Nations.

\section{Article XII}

\section{Rights Granted apart from the Principles}

Nothing in these articles shall be deemed to impair any higher rights and benefits granted or which may hereafter be granted by a State to refugees.

\section{Article XIII \\ Cooperation with International Organizations}

States shall cooperate with the Office of the United Nations High Commissioner for Refugees and, in the region of its mandate, with the United Nations Relief and Works Agency for Palestine Refugees in the Near East.

B. Communication Received from Member States in Response to the Letter of the Secretary General of the AALCO dated 3 July 2000

\section{(i) Botswana}

The State Practice of the Republic of Botswana in Relation to the Jurisdictional Immunities of States and their Properties

"As far as can be discerned, there are no decisions related to Jurisdictional Immunities of States and their Properties that have been rendered by our national courts.

With regard to national legislation, as yet, we have no set statute dealing specifically with the above mentioned area of the law. Furthermore, upon diligent research into this field it was found that regrettably, no relevant material indicative of the jurisprudence and State practice on this topic could be found." [Letter from the Attorney General's Chambers, dated 15 August 2000.]

\footnotetext{
5 During the Open-ended Working Group Meeting held in New Delhi on 26-27 February 2001, the delegate of India proposed the addition of the words "or any other country" after "country of refuge". The proposal was supported by Ghana and Turkey, and approved by the Working Group.
} 


\section{(ii) Japan}

\section{Japanese State practice related to Sovereign Immunity}

\section{National Legislation}

Japan has no legislation on Sovereign Immunity.

2. Decisions related to Sovereign Immunity rendered by the national courts (see Attachment 1).

3. Other Materials indicative of Japanese State practice (see Attachment 2).

\section{Attachment 1}

\section{Decision by the Supreme Court on 28 December 1928 Matsuryama et al. v. Republic of China \\ Summary of the Facts and Judgement:}

The plaintiff claimed payment for the promissory note issued by the Chargé d'Affaires of the defendant State. The courts of the first and second instances decided that, since the defendant had not waived its immunities, no service of writ from the Court could be done. The (former) Supreme Court upheld the conclusion of these decisions of the lower Court, stating that "the service undertaken by the Court and its designation of the date of subpoena is tantamount to the exercise of Japan's sovereign power, and therefore, they cannot be enforced upon a foreign State which is not to be subjected to our sovereignty". The Court further states: "Since a State is not to be subject to another State except by the former's self-restraint, a foreign State does not, in principle, come under Japan's jurisdiction with regard to civil procedures excepting suits concerning immovable property. However, it is an established rule of international law that, only in the case that the foreign State in question voluntarily submits itself to our jurisdiction, it will be an exception. Such an exception could be stipulated for in a treaty or could be made as an ad hoc expression of its jurisdiction submission with regards to a specific suit in question. However, such an expression should always be made vis-à-vis the State of Japan by the said foreign State. Even if there is an agreement between the foreign State and a Japanese subject according to which the former agrees to submit itself to the jurisdiction of Japan, this does not automatically give effect to oblige the said foreign State to actually submit to our jurisdiction".

\section{Decision by the District Court of Tokyo of 9 June 1954 Limbin Hteik Tin Lat v. Union of Burma Summary of the facts:}

The claimant filed with the Court an application for provisional disposition to determine the provisional status of a piece of land to which he claimed title. The land in question, situated next to the premises of the Burmese Consulate-General in Tokyo, was actually purchased in 1944 by A (third party in the present case), father-in-law of the claimant and the then Burmese Ambassador to Japan. The claimant purchased the land in question in 1953 from the wife and daughter of A., who were his joint legal successors under Burmese law. He came to Japan, obtained delivery of the land then in the possession of the administrator, and completed the registration of the transfer on the ground of purchase. 
The respondent, the Government of the Union of Burma, was of the view that the purchase of the land in question was made by A in his capacity as agent of the respondent, so that the title to the land belonged to the latter. The respondent sought a provisional disposition for the striking out of the registration, which the Court granted. The claimant thereupon filed with the Court the present application for provisional disposition in order to prevent disturbance to his title and possession of the land.

The point at issue before the Court was whether a Japanese court had jurisdiction in a case in which the respondent was a foreign State.

\section{Excerpts from the Judgement}

The respondent, the Union of Burma, is known to the Court to have achieved independence a few years ago; it has a Government and controls a certain territory and its people, and has its consuls stationed in his country. In the absence of proof of the existence of special circumstances, such as the fact that the Union does not exercise exclusive control over its territory and its people, the Union must be recognized as a foreign State for the purpose of civil proceedings, even if Japan has not recognized it.

A State is not subject to the exercise of power by another State, and thus is not subject to the jurisdiction of another State in the matter of civil proceedings. This is to be admitted as a principle of international law recognized in general. However, it need hardly be added that in cases where a foreign State has consented by agreement to submit to the jurisdiction of another State, or where a State has waived its immunities that State may be subject to the jurisdiction of another State. Again, in an action concerning an immovable, it is widely admitted that jurisdiction belongs exclusively to the State of the situs, and consequently it must be said that a foreign State may be subject to the jurisdiction of another State.

In general, there is as yet no clearly recognized principle of international law on the question of jurisdiction in international cases, so that each State has to determine the extent of its jurisdiction. Consequently, such a determination, even if not respected by foreign States, is nonetheless valid in the sphere of municipal law of the State making the determination, and as a result clearly gives a basis for the exercise of jurisdiction against a foreign State. However, there is in our law no provision determining the extent of such jurisdiction, and the question must be judged by international customs and other factors. In this respect, there is no denying the fact that an immovable is an object par excellence of the territorial sovereignty of the State of its situs and this fact has been regarded as worthy of respect as a matter of international comity; hence, it has come to be recognized for a long time that an action directly concerning an immovable comes within the exclusive jurisdiction of the State of the situs. It has to be admitted therefore that, judging from its motive and its history, this principle has been recognized as applicable in actions in which a foreign State is a party, as well as where a private person is a party. 
Accordingly ... It has to be concluded that Japan has jurisdiction, and the present Court has competence over the present proceedings in which the Union of Burma is designated as respondent.

With regard to the designation of the Burmese Consul-General as an agent of the respondent, the Court said: "Although in principle [the] Consul-General is considered according to international law not to have authority to represent his State at the diplomatic level, whether he is endowed with the authority to represent his State in civil proceedings is a matter to be decided solely by reference to the legal system of the Union of Burma." The Court concluded from the evidence that he was endowed with such authority.

On the question of the propriety of serving the writ of summons on his person, the Court admitted that such service was not in general permissible if the ConsulGeneral enjoyed diplomatic privileges and immunities. The Court continued: "In cases where the Union of Burma, as respondent, should be subjected to our jurisdiction, the exercise of jurisdiction has to that extent to be recognized, and it cannot be regarded as contrary to international custom to serve the writ on his person, even when he has privileges as head or a member of the diplomatic mission and inviolability with regard to his residence, etc."

\section{Attachment 2}

(Provisional Translation)

Notification of the Secretary General of the Supreme Court to the Presidents of the High Courts and of the District Courts amended 14 December 1996 (originally issued on 15 April 1974)

(Note: This notification was abolished on 20 April 2000)

(Inquiry about the intention of a foreign State of appearing in the proceedings in a civil suit against the State)

The following has been decided with regard to the above mentioned inquiry. The Courts are requested to be in conformity with this. The Presidents of the competent District Courts shall transmit this notification to their subordinate Summary Courts.

1. When a civil action is instituted against a foreign State, the competent court shall in advance request the Supreme Court to inquire through the Ministry of Foreign Affairs about the intention of the defendant State of appearing in the proceedings (see annexed request format).

2. The competent court, in making the request mentioned in paragraph 1 , shall annex a document which summarizes the claims or a copy of the written complaint, accompanied by a translation, if possible, into the official language of the defendant State (if not into English).

(Letter from the Embassy of Japan in New Delhi dated 26 September 2000.) 
(iii) Myanmar

The State Law and Order Restoration Council

The State-owned Economic Enterprises Law

(The State Law and Order Resolution Council Law No. 9/98)

The 10th Waning Day of Tabaung, 1350 M.E. (31 March 1989)

The State Law and Order Restoration Council Hereby enacts the following law:

\section{Chapter I \\ Title and Definition}

1. This Law shall be called the State-owned Economic Enterprises Law.

2. The expression "Government" contained in this Law includes departments, corporations and other organizations under the Government.

\section{Chapter II}

\section{Economic Enterprises to be Carried out Solely by the Government}

3. The Government has the sole right to carry out the following economic enterprises as State-owned economic enterprises:

(a) extraction of teak and sale of the same in the country and abroad;

(b) cultivation and conservation of forest plantation with the exception of villageowned fire-wood plantations cultivated by the villagers for their personal use;

(c) exploration, extraction and sale of petroleum and natural gas and production of products of the same;

(d) exploration and extraction of pearl, jade and precious stones and export of the same;

(e) breeding and production of fish and prawn in fisheries which have been reserved for research by the Government;

(f) Postal and Telecommunications Services;

(g) Air Transport Service and Railway Transport Service;

(h) Banking Service and Insurance Service;

(i) Broadcasting Service and Television Service;

(j) exploration and extraction of metals and export of the same;

(k) Electricity Generating Services other than those permitted by law to private and cooperative electricity generating services;

(1) manufacture of products relating to security and defence, which the Government has, from time to time, prescribed by notification.

4. The Government may, by notification, permit in the interest of the Union of Myanmar any economic enterprise which is prescribed under Section 3 to be operated solely the Government to be carried out by Joint venture between the Government and any other person or any other economic organization or under conditions by any person or any economic organization subject to conditions. 
5. The Government may, by notification, prohibit or prescribe conditions regarding the purchase, procurement, improvement, storage, possession, transport, sale and transfer of products derived from or produced by or used by economic enterprises which are prescribed under Section 3 to be carried out solely by the Government.

\section{Chapter III \\ Right of Carrying Out Other Economic Enterprises}

6. Any person shall have the right to carry out any economic enterprise other than those prescribed under Section 3 to be carried out solely by the government.

7. Without prejudice to the provision of Section 6, the Government may, in addition to those economic enterprises which are prescribed under Section 3 to be carried out solely by the Government, also carry out any other economic enterprise if it is considered necessary in the interest of the Union of Myanmar.

\section{Chapter IV \\ Right to Form an Organization}

8. (a) In order to carry out the economic enterprise mentioned in Section 3 and Section 7, the Government may, by notification:

i) constitute organizations which are to undertake responsibility, and prescribe their duties and powers;

ii) re-constitute, if necessary, such organizations which are in existence at the time of the commencement of this Law, amend and prescribe their duties and power;

iii) constitute one or more bodies to supervise the organizations mentioned in such Sections (i) and (ii), if necessary, and prescribe their duties and powers.

(b) The respective organizations constituted under sub-section (a) shall be a body corporate having perpetual succession and a common seal, and shall have the right to sue and be sued in its corporate name.

\section{Chapter V \\ Offences and Penalties}

9. Whoever is convicted of an offence of carrying out, without the permission of the Government, any economic enterprise prescribed under Section 3 to be carried out solely by the Government, shall be punished with imprisonment for a term which may extend to a period of five years and may also be liable to a fine. Furthermore, property both movable and immovable relating to the economic enterprise may be confiscated. 
10. Whoever is convicted of an offence of violating an order or any condition notified under Section 4 or Section 5 shall be punished with imprisonment for a term which may extend to a period of three years and may also be liable to a fine.

\section{Chapter VI \\ Miscellaneous}

11. For the purpose of carrying out the provisions of this Law, the Government may prescribe such procedures as may be necessary, and the respective Ministers may issue such orders and directives as may be necessary.

12. The Law conferring powers for Establishing the Socialist Economic System, 1965 is hereby repealed.

Sd./Saw Maun

General

Chairman

The State Law and Order Resolution Council

(Letter from H.E. the Ambassador of Myanmar in New Delhi, dated 4 September 2000)

\section{(iv) Mauritius}

We wish to bring to His Excellency's kind attention the following provisions of the States Proceedings Act:

(a) Section 13 of which

(i) broadly speaking, prevents an order for specific performance from being made against the State and instead, provides for declaratory relief in lieu of an order for specific performance to be issued;

(ii) provides that in proceedings against the State for the recovery of land or other property, a declaration rather than order for the recovery of property may be made by a Court of Law;

(b) Section 17(4) of which precludes the Courts from issuing attachment orders against the State for enforcing the payment by the State or any Government Department of a sum of money.

It may however be noted that the State is otherwise liable to be sued and to have judgement delivered against it just as any subject may be sued and have judgement given against him.

Please accept, Excellency, the assurances of our highest consideration. 
F.-Explanatory Note sent by the Government of India on the item entitled "International Terrorism" for inclusion as an additional item on the Agenda of the 40th Session of AALCO

\section{Draft comprehensive Convention on International Terrorism}

\section{Introduction}

It may be recalled that India circulated a draft of a Comprehensive Convention on International Terrorism in the 51st UNGA in 1996. The Resolution 53/108 on "Measures to Eliminate International Terrorism" adopted by 53rd UNGA in 1998 gave the legislative mandate to elaborate the draft Convention on a priority basis, once negotiations on draft Conventions on Nuclear Terrorism and Funding of Terrorist Activities have been completed. At the 54th UNGA in 1999, it was decided that negotiated discussions on the Indian draft would commence in the Ad Hoc Committee on International Terrorism in September 2000. Pursuant to the UNGA Resolution of 1999 on Measures to Eliminate International Terrorism, a Working Group of the Sixth Committee on International Terrorism (A/C.6/55/1), as proposed by India, from 25 September to 6 October 2000 . The second round negotiations on the draft Convention took place from $12-23$ February 2001.

Salient features of the draft Convention:

i. The Preamble recognizes the responsibility of States for suppressing acts of international terrorism including those which are committed or supported by States, directly or indirectly.

ii. The scope of the Convention is defined by Article 2. Under the Convention, a person commits an offence if that person, by any means, unlawfully and intentionally causes death or serious bodily injury or serious damage to property including State or Government facilities, the public transportation system or infrastructure facilities, when the purpose of such act is to intimidate a population, or to compel a Government or an international organization to do or to abstain from doing any act.

The offences covered by the draft Convention are not covered in any other Convention. The definition is comprehensive as it covers "any means" used in the commission of a terrorist offence. The expression "any means" would thus cover the entire range of devices or substances which could be used for committing terrorism. The definition also contains a threshold which separates a terrorist offence from a common street crime.

iii. Article 2(3) of the draft Convention includes the principle of command responsibility which was already accepted by the international Convention for the Suppression of Terrorist Bombings. 
iv. Article 7 lays down the duty on States to refuse the granting of asylum to those involved in the commission of offences covered by the Convention.

v. Article 5 is the political exception clause under which the offences covered in the draft Convention can under no circumstances be justified by considerations of a political, philosophical, ideological, racial, ethnic, religious or other similar nature.

vi. The responsibility of contracting States to ensure that their respective territories are not used for the establishment of terrorist installations and training camps is reflected in Article 8. Under this article the States are required to take effective measures to prohibit:

(a) the establishment and operation of installations and training camps for commission, within or outside their territories, of offences covered by the draft Convention; and

(b) illegal activities of persons, groups and organizations that encourage, organize, knowingly finance or engage in the commission of offences covered by the draft Convention.

vii. Article 14 reinforces the political exception clause and states that extradition and mutual legal assistance may not be refused solely on the grounds that it concerns a political offence or an offence inspired by political motives.

viii. The draft Convention also lays down the duty to prosecute or extradite fugitive offenders.

$\cdots$

\section{Secretariat Study: International Terrorism}

\section{Background Note}

It may not be an exaggeration to say that no other issue has attracted such world-wide attention as has combating international terrorism. Its complex character involving political, ideological, racial and religious issues has defied attempts to reach any international consensus on what constitutes terrorism. Notwithstanding such a lack of legal definition of "terrorism", there are several bilateral and regional agreements, and international conventions to deal with specific situations for the suppression of terrorism which provide the legal framework to establish and promote cooperation among States to deal with this problem. The recent move to draft a comprehensive international convention on terrorism under the auspices of the United Nations is yet another opportunity for the international community to take a concerted approach to combat this menace.

It may be recalled that as early as in 1937, a Convention on Prevention and Punishment of Terrorism was negotiated under the auspices of the League of Nations; it was ratified only by India and never came into force. 
In the aftermath of the Second World War, the establishment of the United Nations was a historic achievement of the twentieth century. The UN Charter set out comprehensive provisions to deal with international peace and security, economic, social, human rights, and scores of other issues. In the wake of the call of the United Nations to end colonialism, liberation movements arose towards gaining independence, but unfortunately various unrecognized groups gathered momentum in several parts of the world. The means and methods advocated by such unrecognized groups added a new dimension to the problem of defining "terrorism" and to drawing a line between these liberation movements and the terrorist groups. It gave rise to "State terrorism", either sponsored or clandestinely supported by them, and resulted in the disruption of civil aviation and maritime navigation, attacks, on diplomatic personnel and civilian targets, and hostage taking by terrorist groups. In order to deal with these emerging issues, it was felt that instead of a comprehensive approach, a sector-wise approach addressing specific situations would be more practical and result-oriented.

The General Assembly as early as in 1972 took up for consideration an item on measures to prevent international terrorism, the convening under the auspices of the United Nations of an international conference to define international terrorism and to differentiate it from the struggle of peoples for national liberation. The resolutions adopted by the General Assembly on subsequent occasions, besides condemning such acts, among other aspects drew attention to the urgency for the conclusion of special agreements on a bilateral, regional and multilateral basis. ${ }^{6}$ Parallel to these developments, international and regional instruments were developed under the ICAO, IMO, IAEA, and some regional organizations. However, a comprehensive approach to deal with the entire gamut of problems of international terrorism remained a matter of universal concern.

Against this backdrop, a major initiative under the United Nations was the adoption of the Declaration on "Measures to Eliminate International Terrorism" on 9 December 1994 by the General Assembly at its 49th Session. It was a significant achievement in its efforts to deal with the problem of international terrorism.

The Declaration, while expressing concern over the world-wide persistence of acts of international terrorism in all its forms and manifestations, including those in which States are directly or indirectly involved, recognized the desirability for connected co-ordination and operation among States in combating crimes closely connected with terrorism, including drug trafficking, unlawful arms trade, money laundering, and the smuggling of nuclear and other potentially deadly materials. It stressed the imperative need for further international co-operation between States in order to take and adopt practical and effective measures to prevent, combat and

6 The various resolutions adopted by the General Assembly include: Re.3034(XXVII) of 18 December 1972, 31/102 of 15 December 1976, 32/147 of 16 December 1977, 34/145 of 17 December 1979, 36/109 of 10 December 1981, 38/130 of 19 December 1983, 40/61 of 9 December 1985, 42/159 of 7 December 1987, 44/29 of 4 December 1989, 46/51 of 9 December 1991, $49 / 60$ of 9 December 1994, 50/5 of 18 October 1995, 50/53 of 11 December 1995, 51/210 of 17 December 1996, 52/165 of 15 December 1997, 53/108 of 8 December 1998, 54/110 of 9 December 1999, and $55 / 158$ of 12 December 2000 . 
eliminate all forms of terrorism that affect the international community as a whole. It recalled the existing international treaties relating to various aspects of the problem and welcomed the conclusion of regional agreements and declarations to combat and eliminate terrorism in all its forms and manifestations.

The solemn Declaration by States was further expanded in subsequent provisions of the Declaration. These, among others, include:

i) Reaffirmation of unequivocal condemnation of all acts, methods and practice of terrorism as criminal and unjustifiable wherever and by whomever committed;

ii) Taking of effective and resolute measures in accordance with relevant provisions of international law and international standards of human rights for the speedy and final elimination of international terrorism. Such measures would include: the apprehension and prosecution or extradition of perpetrators of terrorist acts, co-operation and the exchange of relevant information, and

iii) Adherence to international conventions and protocols relating to various aspects of international terrorism.

The Declaration envisaged an important role for the United Nations, the relevant specialized agencies and inter-governmental organizations and other relevant bodies in promoting measures to combat and eliminate acts of terrorism. it suggested certain practical measures which the Secretary General of the United Nations could initiate with a view to assisting in the implementation of the Declaration. These measures could include:

(a) a collection of data on the status and implementation of existing multilateral regional and bilateral agreements relating to international terrorism;

(b) the preparation of a compendium of national laws and regulations, and

(c) an analytical review of existing international legal instruments, identifying aspects not covered by those instruments which could be subjects for the development of a further comprehensive legal framework.

Finally, the Declaration urged all States to promote and implement in good faith and effectively its provisions in all aspects.

The General Assembly at its 51st Session adopted Resolution 51/210 reaffirming the 1994 Declaration and approved another Declaration as a supplement to it. The General Assembly also decided to establish an Ad Hoc Committee open to all States Members of the United Nations or member of specialized agencies or of the International Atomic Energy Agency, and mandated it to elaborate an international convention for the suppression of terrorist bombings, as well as a further convention on the suppression of acts of nuclear terrorism. 
During the year 1997, the Ad Hoc Committee met twice and completed the preparation of the text of the draft international Convention for the Suppression of Terrorist Bombings. It was adopted by the General Assembly at its 52nd Session on 15 December 1997.

The Ad Hoc Committee during its Session held 17-27 February 1998 focused its discussion on matters concerning the elaboration of an international convention for the suppression of acts of nuclear terrorism. The Report of the Ad Hoc Committee containing a draft text of the Convention on the Suppression of Acts of Nuclear Terrorism was further considered by a working group of the Sixth Committee which met from 28 September to 9 October 1998, during the 53rd Session of the General Assembly. In spite of several informal consultations, the Working Group failed to arrive at a consensus on the issues concerning the scope of the Convention. The General Assembly at its 53rd Session took note of the progress of work in the Ad Hoc Committee and directed it to continue to elaborate the draft Convention for the Suppression of Acts of Nuclear Terrorism and also to initiate consideration of the draft Convention on the Suppression of Financing of Terrorism, taking as a basis for discussion the draft text submitted by the delegation of France to the Sixth Committee. During the 53rd Session, the delegation of India proposed the adoption of a comprehensive convention against international terrorism and circulated a draft text on the same.

The Ad Hoc Committee during its meetings in 1999 devoted its time to the consideration of the outstanding issues relating to the two draft conventions. This work continued within the framework of a Working Group of the Sixth Committee convened during the 54th Session of the General Assembly from 27 September to 8 October 1999. The Working Group was able to finalize the draft articles on the International Convention for the Suppression of the Financing of Terrorism, which was later adopted by the General Assembly at its 54th Session.

In its resolution adopted on 9 December 1999, the General Assembly decided that the Ad Hoc Committee, besides considering the outstanding issues relating to the elaboration of the draft Convention on the Suppression of International Terrorism, would also address the question of convening a high-level conference under the auspices of the United Nations to formulate a joint organized response of the international community on terrorism in all of its forms and manifestations, as well as the elaboration of a comprehensive convention on international terrorism.

The Fourth Session of the Ad Hoc Committee was held in New York from 14 to 18 February 2000. It elected Rohan Perera (Sri Lanka) as Chairman; Cate Steains (Australia) as Vice-Chairperson and Co-ordinator, and Ivo Jande (Czech Republic) as Rapporteur. The debate in the Ad Hoc Committee focused on matters relating to the draft Convention on the Suppression of Acts of Nuclear Terrorism and the convening of a high-level United Nations Conference to formulate a joint organized response to terrorism in all its forms. In addition, general comments were also made by delegations on the importance of preparing a comprehensive legal framework international terrorism. The Ad Hoc Committee could not complete its work on the draft Convention on the Suppression of Nuclear Terrorism. The Co-ordinator for consultations reported that the outstanding issues revolved around the "scope provi- 
sion" in the text and "the differences on the substance were too fundamental and polarized".

The next round of discussions was held during the 55th Session of the General Assembly in the Working Group of the Sixth Committee, which met from 25 September to 6 October 2000. The Working Group decided to invite the representatives of the International Committee of the Red Cross (ICRC), the Commonwealth Secretariat, the European Union (EU), the League of Arab States, and the Organization of African Unity (OAU) to participate in its discussions as observers.

The Working Group continued its discussion on a revised text of the draft Convention on the Suppression of Acts of Nuclear Terrorism prepared by the friends of the Chairman, and the working document submitted by India entitled "Draft comprehensive convention on international terrorism", a revised version of its previous text, as well as proposals submitted by other delegations.

During the course of the discussions in which some delegations reiterated the convention on international terrorism, attention focused on the revised text submitted by India, especially on Article 5 (the depoliticization clause), the limitation on the granting of asylum, Article 8 (the obligation to cooperate in the prevention of terrorist acts), and Article 11 (the extradite or prosecute principle). The necessity for the inclusion of a definition of terrorism was stressed by some delegations. It was suggested that a provision should be made for the recognition of State terrorism. Others felt that the conduct of a State could not fall within the ambit of terrorism. Some delegations suggested the need for drawing a distinction between terrorism, on the one hand, and the legitimate struggle, on the other, of people in the exercise of their right to self-determination, as well as the right of self-defence against aggression and occupation. There were divergent views on the scope of the draft convention and its relationship to existing international conventions on terrorism. It was suggested that the provisions and approach adopted by the regional conventions concluded in various regions could provide useful guidance.

There were as many as 38 written proposals submitted by various delegations. Among them, the proposals submitted by AALCO Member States, besides India, included: Lebanon (Article 2); Sudan (Articles 2 and 3); the Syrian Arab Republic (Article 6, para 2(d)); Lebanon (Article 6, para 2); Sri Lanka and Turkey (Article 7); Syria (Article 11, para 2); Nigeria (Article 2, para 1); Qatar (Article 18); Lebanon and Syria (new Preamble paragraph; Lebanon and Syria (Articles 1 and 18).

The Fifth Session of the Ad Hoc Committee was held in New York from 12 to 23 February 2001; some delegations stressed the need for the speedy finalization of the text of the draft International Convention for the Suppression of Acts of Nuclear Terrorism. Elaborate discussions were held on the two other issues, namely, the question of convening a high-level conference under the auspices of the United Nations to formulate a joint organized response of the international community to terrorism in all its forms and manifestations, and the elaboration of a draft Comprehensive Convention on International Terrorism.

As regards the question of convening a high-level conference, no consensus emerged. Some delegations felt that the convening of such a conference would help expedite the conclusion of a comprehensive international convention; other delegations 
were of the view that prior to a decision to convene such a conference, it would be desirable first to consider carefully the objective and possible outcome of such a conference.

On the issues concerning the elaboration of a draft Comprehensive Convention on International Terrorism, the discussions were able to make good progress, despite the fact that there was no consensus on certain key issues. Among these were the scope of the conventions and the relationship of the convention to other anti-terrorism conventions.

Malaysia, on behalf of the organization of the Islamic Conference Group, proposed the inclusion of definitions of the terms "terrorism" and "terrorist crime" based on General Assembly Resolution 46/51 of 9 December $1991^{7}$ and in accordance with the provision on the Convention of the Organization of Islamic Conference on Combating International Terrorism. Some delegations were not in favour of such a proposal. In their view, Article 2 of the revised draft text provided an operational definition as set out in the phrase "within the meaning of this convention". A suggestion was made to redraft Article 2 so that "terrorist acts" could be indicated more clearly in the text. Some delegations reiterated that the definition of terrorism must differentiate between terrorism and legitimate struggle in the exercise of the right to the self-determination and independence of all peoples under foreign occupation.

There were divergent views on the exclusion of the activities of armed forces, the application of international humanitarian law conventions, and covering acts of State-sponsored terrorism within the definition of terrorism in the proposed convention.

The discussion on the possible relationship between the proposed convention and sectoral anti-terrorism conventions already in force remained inconclusive.

As directed by the General Assembly at its 55th Session, the next round of negotiations will be held within the framework of a working group of the Sixth Committee, from 15-26 October 2001.

\section{General Comments}

There is wide support from the international community to take concerted and strong action against world-wide acts of terrorism which are criminal in nature.

\footnotetext{
7 Paragraph 15 of Resolution 46/51 of 9 December 1991 "considers that nothing in the present resolution could in any way prejudice the right to self-determination, freedom or independence, as derived from the Charter of the United Nations of people forcibly deprived of that right referred to in the Declaration of the Principles of International Law concerning Friendly Relations and Cooperation among States in accordance with the Charter of the United Nations, particularly peoples under colonial and racist regimes or other forms of alien domination, or the right of these peoples to struggle legitimately to this end and to seek and receive support in accordance with the principles of the Charter, the above-mentioned Declaration and the relevant General Assembly resolution including the present resolution."
} 
It is a matter of great satisfaction that the issues concerning international terrorism have received a good deal of attention in many other fora apart from the United Nations. The Twelfth Conference of Heads of States or Governments of Non-aligned Countries held in Durban, South Africa, on 2 and 3 September 1998 reaffirmed its collective position on terrorism and called for the convening of an international summit under the auspices of the United Nations to formulate a joint organized response of the international community to terrorism in all its forms and manifestations. The Organization of American States (OAS) at an Inter-American Specialized Conference on Terrorism adopted the Lima Declaration and Plan of Action to Prevent, Combat and Eliminate Terrorism held on 23 and 24 November 1998 at Mar del Plata, Argentina, in which the progress made subsequent to the adoption of the Lima Declaration was evaluated and the Inter-American Committee against Terrorism (CICTE) was established. More recently, the Organization of African Unity, the League of Arab States and the Organization of Islamic Conference have adopted conventions to combat terrorism.

The comprehensive international convention to combat terrorism which is being negotiated under the auspices of the United Nations would be a major step towards complementing the existing network of anti-terrorism conventions.

The draft text of the convention submitted by the Government of India has provided a sound basis for the negotiation of a comprehensive text. While considerable progress has been made in narrowing down the divergent views on many issues, there are a few key remaining issues which deserve the utmost attention.

As was the exercise to achieve consensus on the definition of "aggression", which took several years, the attempt to define "terrorism" is also a challenging task; without achieving that objective, the accomplishment of the proposed international convention on terrorism would remain incomplete.

Issues concerning "State terrorism" may be dealt with under State responsibility and violations of international law. However, the obligation not to provide a "safe haven" to terrorism by any State, nor to encourage or support such activities under any pretext, should be a core commitment under the proposed convention.

The inalienable right to self-determination and to struggle against a colonial and racist regime are well recognized principles of international, and had been endorsed by the General Assembly of the United Nations in its numerous resolutions. The Declaration on Measures to Eliminate International Terrorism adopted by the General Assembly on 9 December 1994 and the Declaration on the occasion of the Fiftieth Anniversary of the United Nations, adopted on 24 October 1995, reaffirmed the right of self-determination of all peoples, taking into account the particular situation of peoples under colonial or other forms of alien domination or foreign occupation, and recognized the right of peoples to take legitimate action in accordance with the Charter of the United Nations to realize their inalienable right of self-determination. Any attempt to undermine those rights would remain a stumbling block in achieving consensus on the convention on terrorism.

The proposed comprehensive international convention should complement the existing legal regime of the anti-terrorism conventions. Indeed, it should be a step 
forward and constitute an "umbrella" convention under which that regime could be further strengthened.

There are several regional conventions which set out effective provisions for promoting cooperation among States to deal with terrorism issues. Their examples and experience could benefit the on-going negotiations in the Ad Hoc Committee.

The crux of the effective implementation of the proposed convention would be to promote cooperation among the law enforcement agencies to act jointly and to take measures to prevent, detect and investigate acts of terrorism. The obligations of the States in this respect in the proposed convention should be elaborated in precise terms such that no loopholes for any subjective interpretation are left.

It is interesting to note that a Terrorism Prevention Branch of the Centre for International Crime Prevention has been established in Vienna, under the auspices of the United Nations. Since the increase in the number of terrorist groups' activities around the world and their growing capability and financial resources to obtain sophisticated weapons have made the international terrorism problem more serious, the Centre in Vienna could collect and provide useful information to the governmental agencies and other interested inter-governmental organizations involved in anti-terrorist operations. The cooperation of Interpol in this respect would further strengthen the measures to contain and eliminate international terrorism.

There are as many as 19 international and regional conventions which have been adopted over the years to deal with specific situations or in general concerning the issues of terrorism. The wider participation and increasing ratification by State which are not yet parties to those conventions should be one of the prime objectives in the meantime, until the proposed comprehensive convention sees the light of day.

The proposal to convene a high-level conference on terrorism has gained wide support. In order to gain further support, it would be desirable to prepare a precise outline of the issues for consideration. In addition, the timing and level of participation need to be considered. The idea of convening a meeting of technical and legal experts and law enforcement officials to do the preparatory work is a practical step. The holding of an international conference at a high level would demonstrate the determination of the international community to face the challenge posed by international terrorism.

The Asian-African Legal Consultative Organization, being a regional intergovernmental organization engaged in the field of international law, may also contribute to strengthening the legal framework to combat terrorism. The Member States may wish to identify the areas in which useful work can be taken up by the AALCO Secretariat. The Ad Hoc Committee at its last meeting has opened the door for participation in the ICRC, the European Union, the Commonwealth Secretariat, the OAU and the League of Arab States as observers. The AALCO may also consider representation in the meeting of the Ad Hoc Committee scheduled to be held in New York from 15 to 26 October 2001. 


\section{ANNEX \\ List of International and Regional Legal Instruments Related to the Prevention and Suppression of International Terrorism}

\section{A. International Conventions}

(i) Convention on Offences and Certain Other Acts Committed on Board Aircraft, signed at Tokyo on 14 September 1963 (entered into force on 4 December 1969);

(ii) Convention for the Suppression of Unlawful Seizure of Aircraft, signed at The Hague on 16 December 1970 (entered into force on 14 October 1971);

(iii) Convention for the Suppression of Unlawful Acts against the Safety of Civil Aviation, signed at Montreal on 23 December 1971 (entered into force on 26 January 1973);

(iv) Convention on the Prevention and Punishment of Crimes against Internationally Protected Persons, including Diplomatic Agents, adopted by the General Assembly of the United Nations on 14 December 1973 (entered into force on 20 February 1977);

(v) International Convention against the Taking of Hostages, adopted by the General Assembly of the United Nations on 17 December 1979 (entered into force on 3 June 1983);

(vi) Convention on the Physical Protection of Nuclear Material, signed at Vienna on 3 March 1980 (entered into force on 8 February 1987);

(vii) Protocol for the Suppression of Unlawful Acts of Violence at Airports serving International Civil Aviation, supplementary to the Convention for the Suppression of Unlawful Acts against the Safety of Civil Aviation, signed at Montreal on 24 February 1988 (entered into force on 6 August 1989);

(viii) Convention for the Suppression of Unlawful Acts against the Safety of Maritime Navigation, done at Rome on 10 March 1988 (entered into force on 1 March 1992);

(ix) Protocol for the Suppression of Unlawful Acts against the Safety of Fixed Platforms Located on the Continental Shelf, done at Rome on 10 march 1988 (entered into force on 1 March 1992);

(x) Convention on the Marking of Plastic Explosive for the Purpose of Detection, signed at Montreal on 1 March 1991 (entered into force on 21 June 1998); 
(xi) International Convention for the Suppression of Terrorist Bombings, adopted by the General Assembly of the United Nations on 17 December 1997;

(xii) International Convention for the Suppression of the Financing of Terrorism, 1999.

\section{B. Regional Conventions and Instruments}

(i) European Convention on the Suppression of Terrorism, concluded at Strasbourg on 27 January 1977 (entered into force on 4 August 1978);

(ii) OAS Convention to Prevent and Punish Acts of Terrorism Taking the Form of Crimes Against Persons and Related Extortion that are of International Significance, concluded at Washington, D.C. on 2 February 1971 (entered into force on 16 October 1973);

(iii) Declaration and Plan of Action of Lima to Prevent, Combat and Eliminate Terrorism, 1996;

(iv) SAARC Regional Convention on Suppression of Terrorism, signed at Kathmandu on R November 1987 (entered into force on 22 August 1988); all seven States Members of SAARC (Bangladesh, Bhutan, India, Maldives, Nepal, Pakistan and Sri Lanka) are Parties to the Convention;

(v) Arab Convention on the Suppression of Terrorism, 1999, concluded under the auspices of the Organization of Islamic Conference;

(vii) Convention on the Prevention and Combating of Terrorism, 1999, concluded under the auspices of the Organization of African Unity (OAU);

(viii) Treat on Cooperation between the Commonwealth of Independent States (CIS) in Combating Terrorism, 4 June 1999 (Azerbaijan, Georgia, Kazakhstan, Kyrgyzstan, Republic of Moldova, Russian Federation and Tajikistan).

\section{Explanatory note on the item received from the Government of Indonesia}

\section{Establishing Cooperation against Trafficking in Women and Children}

\section{A. Background}

Transnational organized crime is truly international in nature and has increasingly become a global concern since the menace of this crime knows no boundaries. In responding effectively to this crime, domestic legislation and law enforcement in a given country must also be followed by international cooperation among countries, both bilaterally and multilaterally. The rapid growth in the flow of people and goods 
as a result of globalization has brought about dramatic changes in coping with criminality. Without effective law enforcement, criminals will continue to disrupt law and order. It is a matter of common awareness that no country would be able effectively to combat transnational organized crime without fostering international cooperation.

Countries in Asia and Africa, as in other regions, are not immune from the threats inherent in this crime. Economic and social problems have very often affected the protection and welfare of women and children in this region. Women and children are also vulnerable to exploitation committed by transnational organized crime groups. Even though there are no accurate statistics, this problem has become much more alarming and serious.

In this connection, the High Level Political Signing Conference for the UN Convention against Trans-National Organized Crime and Protocol to Prevent Trafficking in Persons, especially Women and Children; and the Protocol against the Smuggling of Migrants were held in Palermo, Italy, from 12 to 15 December 2000. The Government of Indonesia signed these three legal instruments during the conference.

To combat transnational organized crime more effectively, it is necessary to focus the attention on a specific area of this crime. It is a matter of urgency for this region to deal with this matter more comprehensively, since women and children are the most vulnerable as victims of criminals in Asian and African countries. Essentially, the Protocol to Prevent Trafficking in Persons is intended to "prevent and combat" trafficking in persons and to facilitate international cooperation against such trafficking. It provides control and cooperation measures to protect and assist the victims. Trafficking in persons is intended to include a range of cases where human beings are exploited by organized groups, where there is an element of duress involved and a transnational aspect, such as the movement of people across borders or their exploitation within a country by a transnational organized group.

Due to the fact that to prevent and combat this problem effectively cooperation among countries in the Asian and African regions is needed, the Government of Indonesia, therefore, considers it necessary that during the 40th Session of the Asian African Legal Consultative Organization which will be held in Jakarta the problem of trafficking in women and children should be included in the agenda and expected the following items to be our concern, as follows:

- Expecting that those countries who had not yet signed the Protocol to Prevent Trafficking in Women and Children to consider signing it;

- Expecting that those countries who had already signed the Protocol to Prevent Trafficking in Women and Children to consider ratifying it pursuant to their laws and legislation;

- $\quad$ Expecting the countries to implement the Protocol immediately.

Concerning that matter, we really hope to discuss these significant issues, such as:

a. The role of law enforcement in the trafficking in women and children cases;

b. Prosecutorial strategies;

c. Model legislation and international agreement;

d. Intelligence sharing;

e. Effective utilization of resources and initiatives. 


\section{B. Problem in Indonesia}

Trafficking in women has emerged in Indonesia recently as a consequence of the rapid growth in the numbers of Indonesian women migrant workers abroad. Although accurate research and surveys have not yet been conducted properly, trafficking in women has frequently been reported in the press and media. The increase in Indonesian women migrant workers abroad started in 1984, and most are employed as domestic workers. The figures have significantly increased by eight to ten times higher, from 11,180 workers to 85,231 workers in 1992.

The main obstacle to prevent and combat illicit trafficking in women and children in Indonesia stems from the unavailability of exact and accurate data related to this problem. Therefore, international cooperation in information sharing is also significant and necessary in fighting this truly serious crime.

Jakarta, 12 March 2001

\section{Secretariat Study: Establishing Cooperation Against Trafficking in Women and Children}

\section{Background Note Prepared by the Secretariat}

\section{Trafficking in Women and Children}

At the recent United Nations General Assembly Millennium Summit, world leaders proclaimed freedom - from fear and from want - as one of the essential values in the twenty-first century. Yet the right to live in dignity, free from fear and want, is still denied to millions of people around the world.

"I believe the trafficking of persons, particularly women and children, for forced and exploitative labour, including for sexual exploitation, is one of the most egregious violations of human rights which the United Nations now confronts. The fate of these most vulnerable people in our world is an affront to human dignity and a challenge to every state, every people and every community. I therefore urge the Member States not only to ratify the Convention Against Transnational Organized Crime, but also the Protocol to Prevent, Suppress and Punish Trafficking in Persons, particularly trafficking in women and children, which can make a real difference in the struggle to eliminate this reprehensible trade in human beings." These words of Mr. Kofi Annan, the Secretary General of the United Nations, have focused on the problem of trafficking in women and children. ${ }^{8}$

Every day, around the world, women and girls are enticed with the promise of well-paid jobs, bought from their families, or abducted outright and taken to a foreign country for the purpose of sexual exploitation. Escape is nearly impossible. The women are often not allowed to leave the brothel, making communication with the

\footnotetext{
${ }^{8}$ Speech of Mr. Kofi Annan, Secretary General of the UN, delivered at the opening of the Conference for the Convention Against Trans-National Organized Crime in Palermo, Italy, 12 December 2000 .
} 
outside world difficult. If the woman is able physically to free herself, return to her home country may be impossible as pimps frequently keep the woman's only means of return: her passport, airline ticket and money. The risk of arrest and immediate deportation is always present.

For the women who do return home, prostitution, even involuntary, often carries with it a social stigma, making the women into pariahs and thus often also unmarriageable. Lacking opportunities for education or "honest" work, and with no husband or family to support them, the women are often forced into prostitution as the sole means of supporting themselves, thus continuing the cycle of degradation, humiliation and victimization. ${ }^{9}$

\section{What is Trafficking?}

The practice of the sexual exploitation of women continues today. When this exploitation involves the moving of women, the practice is usually termed "trafficking in women". This term was used as early as the end of the 1800 s. There has, however, been confusion as to exactly what is meant by it. The confusion can be seen in the various, often contradictory, definitions and concepts used in domestic law and international conventions, as well as in on-going international debates. Ultimately, however, "trafficking in women" is a complex phenomenon that involves often extremely sensitive issues such as sex and money. According to the International Organization for Migration (IOM), trafficking occurs when:

(a) a migrant is illicitly engaged (recruited, kidnapped, sold, etc.) and moved either within national or across international borders, and

(b) intermediaries (traffickers) obtain economic or other profit by means of deception, coercion and other forms of exploitation under conditions that violate the fundamental rights of migrants. ${ }^{10}$

\section{The subjects of trafficking}

Why women and girls are susceptible to sex traffickers is not difficult to understand. While each woman's situation is unique, there are recurrent trends in the trafficking business. First, the vast majority of women is very poor. ${ }^{11}$ They come from places where women and girls have fewer educational and economic opportunities than do males. Often the girls have been socialized into an ethos of female servitude and

\footnotetext{
9 Trafficking in Women and Children, Diane Johnson, New England School of Law, 1999. http// www.nest.edu/annual/vol.s./johnson.htm

${ }^{10}$ A definition contained in the 18 January 1996 European Parliament goes beyond earlier resolutions which limited the definition of trafficking to include only women, and takes the term "trafficking in human beings" to include men: "the illegal action of someone who, directly or indirectly, encourages a citizen from a third country to enter or stay in another country in order to exploit that person by using deceit or any other form of coercion or by abusing that person's vulnerable situation or administrative status".

${ }^{11}$ Fourth World Conference on Women, Beijing, China, 4-15 September 1995.
} 
self-sacrifice. These conditions, coupled with a preference for sons in many parts of the world, often lead families to sell their daughters for the promise of immediate payment.

There are commonalities on how these women are recruited and the conditions they are forced to endure. Recruitment often occurs with the promise of a good job in another country. It also occurs through false marriage offers, with the bride later sold off to a brothel. Another almost universal theme in trafficking is that most women are held under debt bondage, and are vulnerable under issues related to this form of control.

The women are subject to many risks, such as the physical consequences of prostitution. Besides rape and battery at the hands of customers and pimps, they are exposed to health risks, especially to sexually transmitted diseases including hepatitis $\mathrm{B}$ and HIV/AIDS. Infertility is another serious risk from the forced prostitution that can bring about so many harmful consequences.

\section{Trafficking in children}

As was rightly pointed out by Razali Ismail, President of the Third Committee (social, humanitarian and cultural) of Malaysia, ${ }^{12}$ trafficking is an illegal and clandestine practice and, therefore, it was virtually impossible to estimate the actual numbers of women and children involved. Actual information on the incidence of children was even more fragmented. One fact remained incontrovertible: that a greater number of young girls were absorbed into the commercial sex trade where adult female prostitution existed. Even more disheartening were indications of a growing demand by male clients for sexual activities with very young girls, a trend probably associated with the HIV/AIDS pandemic. Razali Ismail said it was ironic that when globalization and market forces had been accepted as the keystones of greater freedom and prosperity, the most vulnerable women and children had themselves fallen victim to the global zeal for commodification. Despite all of the efforts of the international community, the organized crime of trafficking in women and children had continued.

\section{Existing Legal Framework for the Prevention of Trafficking in Women and Children}

At the global conferences held in Rio de Janeiro, Vienna, Cairo and Copenhagen, the importance of issues related to the improvement of the status of women was stressed. From each of these global conferences emerged a more powerful recognition of the crucial role of women in sustainable development and protecting the environment.

The Vienna Declaration and programme of action ${ }^{13}$ proclaimed: "The human rights of women of the girl child are an inalienable, integral and indivisible part of

12 GA/9189, 75th Meeting, 6 December 1996.

${ }_{13}$ Adopted by the World Conference on Human Rights, Vienna, 25 June 1993 (A/Conf.157/24)(Part

I), Chapter III. 
universal human rights. The full and equal participation of women in political, civil, economic, social and cultural life, at the national, regional and international levels, and the eradication of all forms of discrimination on grounds of sex are priority objectives of the international community".

\section{(A) Convention for the Suppression of Traffic in Persons and of Exploitation of the Prostitution of Others}

The 1949 Convention for the Suppression of Traffic in Persons and of Exploitation of the Prostitution of Others ${ }^{14}$ was the outcome of the concern of the international community towards the effective suppression of trafficking in women and girls which was a matter of pressing international concern.

\section{(B) Convention on the Elimination of All Forms of Discrimination Against Women}

Another turning point was in 1979, when the General Assembly adopted the Convention on the Elimination of all Forms of Discrimination Against Women, which entered into force in $1981^{15}$ and set an international standard for what is meant by equality between women and men.

Although the International Bill of Human Rights ${ }^{16}$ lays down a comprehensive set of rights to which all persons, including women, are entitled, it was necessary to have a separate legal instrument for women; this is because additional means for protecting women were seen as necessary because the mere fact of their "humanity" has not been sufficient to guarantee women the protection of their rights. The preamble to the Convention on the Elimination of All Forms of Discrimination against Women explains that, despite the existence of other instruments, women still do not have equal rights with men. Discrimination against women continues to exist in every society.

The Convention was adopted by the General Assembly in 1979 to reinforce the provisions of existing international instruments designed to combat the continuing discrimination against women. It identifies many specific areas where there has been notorious discrimination against women, for example, in regards to political rights, marriage and the family, and employment. In these and other areas the Convention

\footnotetext{
${ }^{14}$ General Assembly Resolution $317(\mathrm{~N})$, Annex.

15 The Convention has 165 parties, of which 20 are AALCO Member States: Egypt, Gambia, Ghana, India, Indonesia, Iraq, Japan, Jordan, Kenya, Kuwait, Lebanon, Libyan Arab Jamahiriya, Sierra Leone, Singapore, Sri Lanka, Thailand, Turkey, Uganda, United Republic of Tanzania, and Republic of Yemen.

${ }^{16}$ The International Bill on Human Rights is a term used to refer collectively to three instruments: (i) the Universal Declaration of Human Rights; (ii) the International Covenant on Economic, Social and Cultural Rights, and (iii) the International Covenant on Civil and Political Rights, and its two Protocols. Taken together, these instruments form the ethical and legal basis for all of the human rights work of the United Nations and provide the foundation upon which the international system for the protection and promotion of human rights has been developed.
} 
spells out specific goals and measures that are to be taken to facilitate the creation of a global society in which women enjoy full equality with men and thus full realization of their guaranteed human rights.

To combat gender-based discrimination, the Convention requires States Parties to recognize the important economic and social contribution of women to the family and to society as a whole. It emphasizes that discrimination will hamper economic growth and prosperity. It also expressly recognizes the need for a change in attitudes, through the education of both men and women, to accept equality of rights and responsibilities, and to overcome prejudices and practices based on stereotyped poles. Another important feature of the Convention is its explicit recognition of the goal of actual, in addition to legal, equality, and of the need for temporary special measures to achieve that goal. ${ }^{17}$

Article 6 of that Convention deals with suppressing the exploitation of women; it urges States to take all appropriate measures to combat trafficking in women and exploitative prostitution. In addressing these problems, it is essential for States to consider and act upon the conditions which are at the root of female prostitution: underdevelopment, poverty, drug abuse, illiteracy, and the lack of training, education and employment opportunities. States Parties should also provide women with alternatives to prostitution by creating opportunities through rehabilitation, job-training and job-referral programmes.

States that tolerate the existence of exploitative prostitution, girl-child prostitution and pornography, and other slave-like practices are in clear violation of their obligations under this Article. It is not enough to enact laws against such injustices: in order adequately to discharge their responsibilities, States Parties must ensure that measures are taken to implement penal sanctions fully and effectively.

\section{(C) Convention on the Rights of the Child}

The Convention on the Rights of the Child was adopted by the General Assembly in 1989 and entered into force on 2 September 1990, in accordance with its Article 49. By December 1995, no fewer than 185 countries had ratified the Convention. ${ }^{18}$

The Convention on the Rights of the Child has the same meaning for people in all parts of the world. While laying down common standards, the Convention takes into account the different cultural, social, economic, and political realities of individual States so that each State may seek its own means to implement the rights common to all.

\footnotetext{
${ }_{17}$ Discrimination against women: the Convention and Committee, Human Rights Fact Sheet 22, p.4.

18 As of December 2000, 191 countries had ratified the Convention, and 32 Member States of the AALCO were Parties to the Convention: India, Indonesia, Islamic Republic of Iran, Iraq, Japan, Jordan, Kenya, Kuwait, Lebanon, Libyan Arab Jamahiriya, Malaysia, Mauritius, Mongolia, Myanmar, Nepal, Nigeria, Pakistan, Philippines, Qatar, Republic of Korea, Saudi Arabia, Senegal, Sierra Leone, Singapore, Sri Lanka, Sudan, Syrian Arab Republic, Thailand, Turkey, Uganda, United Republic of Tanzania, Republic of Yemen.
} 
There are four general principles enshrined in the Convention. These are meant to help with the interpretation of the Convention as a whole and thereby guide national programmes of implementation. The four principles are formulated, in particular, in Articles 2, 3, 6 and 12.

Non-discrimination (Article 2): States Parties must ensure that all children within their jurisdiction enjoy their rights. No child should suffer discrimination. This applies to every child, "irrespective of the child's or his or her parent's or legal guardian's race, colour, sex, language, religion, political or other opinion, national, ethnic or social origin, property, disability, birth or other status".

The essential message is equality of opportunity. Girls should be given the same opportunities as boys. Refugee children, children of foreign origin, children of indigenous or minority groups should have the same rights as all others. Children with disabilities should be given the same opportunity to enjoy an adequate standard of living.

Best interests of the child (Article 3): When the authorities of a State take decisions which affect children, the best interests of children must be a primary consideration. This principle relates to decisions by courts of law, administrative authorities, legislative bodies, and both public and private social welfare institutions. This is, of course, a fundamental message of the Convention, the implementation of which is a major challenge.

The right to life, survival and development (Article 6): The right-to-life Article includes formulations about the right to survival and to development, which should be ensured "to the maximum extent possible". The term "development" in this context should be interpreted in a broad sense, adding a qualitative dimension: not only is physical health intended, but also mental, emotional, cognitive, social, and cultural development.

The views of the child (Article 12): Children should be free to have opinions in all matters affecting them, and those views should be given due weight "in accordance with the age and maturity of the child". The underlying idea is that children have the right to be heard and to have their views taken seriously, including in any judicial or administrative proceedings affecting them.

The articles which specifically deal with the suppression of trafficking in children are: Article 33 of the Convention which requires States Parties to take all appropriate measures, including legislative, administrative, social and educational measures, to protect children from the illicit use of narcotic drugs and psychotropic substances as defined in the relevant international treaties, and to prevent the use of children in the illicit production and trafficking of such substances.

Article 34 requires States Parties to protect the child from all forms of sexual exploitation and sexual abuse. For these purposes States Parties shall in particular take all appropriate national, bilateral and multilateral measures to prevent: (a) the inducement or coercion of a child to engage in any unlawful sexual activity; (b) the exploitative use of children in prostitution or other unlawful sexual practices, and (c) the exploitative use of children in pornographic performances and materials. 


\section{(D) United Nations Convention against Transnational Organized Crime}

The United Nations Convention against Transnational Organized Crime was adopted by the General Assembly at its Millennium meeting in November 2000. It was opened for signature at a high-level conference in Palermo, Italy, in December 2000. It is the first legally binding UN instrument in the field of crime. It must be signed and ratified by 40 countries before it comes into force.

Of the 189 Member States of the UN, $124^{19}$ had signed this landmark Treaty, with close to 80 of them also signing the Treat's two accompanying Protocols: one to prevent, suppress and punish trafficking in persons, especially women and children, and the other against the smuggling of migrants by land, sea and air.

States Parties to the Convention would be required to establish in their domestic laws four criminal offences: participation in an organized criminal group; money laundering; corruption, and obstruction of justice.

The new instrument spells out how countries can improve cooperation on such matters as extradition, mutual legal assistance, transfer of proceedings, and joint investigations. It contains provisions for victim and witness protection and shielding legal markets from infiltration by organized criminal groups. Parties to the Treaty would also provide technical assistance to developing countries to help them take the necessary measures and upgrade their capacities for dealing with organized crime.

It is hoped that upon ratification the Convention will emerge as the main tool of the international community for fighting transnational crime.

\section{(E) The Protocol to Prevent, Suppress and Punish Trafficking in Persons}

Some of the important aspects of the Protocol have been summarized as follows:

\section{Part I - Purpose, scope and criminal sanctions (Articles 1 - 3)}

Articles 1 and 2 set out the basic purpose and scope of the Protocol. Essentially, the Protocol is intended to "prevent and combat" trafficking in persons as criminal offences, and to require control and cooperation measures against traffickers. It also provides some measures to protect and assist the victims. Some issues remain open with respect to the application of the Protocol to purely domestic activities (e.g., the movement of victims within a country) which support international trafficking.

"Trafficking in person" is intended to include a range of cases where human beings are exploited by organized crime groups where there is an element of duress involved and a transnational aspect, such as the movement of people across borders or their exploitation within a country by a transnational organized crime group.

\footnotetext{
19 Out of these 124 signatory parties, 22 AALCO Member States have signed either the Convention or its Protocols: Arab Republic of Egypt, China, Cyprus, The Gambia, Indonesia, Iran Iraq, Japan, Republic of Korea, Kuwait, Mauritius, Nigeria, Pakistan, The Philippines, Saudi Arabia, Senegal, Singapore, Sri Lanka, Sudan, Syria, Thailand, Republic of Yemen.
} 
The key definition of "trafficking in persons" (Article 2 bis) is not yet finalized, but there is general agreement about core elements. Trafficking is the "... recruitment, transportation, transfer, harbouring or receipt of persons..." if this uses improper means, such as force, abduction, fraud, or coercion, for an improper purpose, such as forced or coerced labour, servitude, slavery or sexual exploitation. The Protocol also contains language to include cases where those who have custody or control over another person, often a child, transfer custody in exchange for improper payments. Countries which ratify the Protocol are obliged to enact domestic laws making these activities criminal offences, if such laws are not already in place (Article 3).

This has been a difficult exercise in drafting and negotiation because of the wide variety of activities many of the countries involved are seeking to control. Some of the more difficult issues which have had to be addressed include the following: Some States have taken the position that, since the major abuses of trafficking involve women and children and these are most in need of protection, the Protocol should be limited to them to focus domestic efforts accordingly. Others felt that abuses against all "persons" should be included. As presently worded, the Protocol applies to all "persons", but generally refers to "... persons, especially women and children ...". Finding language to capture a wide range of coercive means used by organized crime has also proven difficult. With the exception of children, who cannot consent, the intention is to distinguish between consensual acts or treatment and those in which abduction, force, fraud, deception or coercion are used or threatened. As with the Convention, the nature and degree of international and organized crime involvement that should be required before the Protocol applies has also been the subject of extensive discussions, some of which are still ongoing. Generally, cases in which there is little or no international involvement can be dealt with by domestic officials without recourse to the Protocol or Convention for the assistance of other countries. On the other hand, requiring too direct a link might make it impossible to use the Protocol provisions in cases where purely domestic offences were committed by foreign offenders or as part of a larger transnational organized crime scheme.

\section{Part II - Protection of Trafficked Persons (Articles 4 - 6)}

In addition to taking action against traffickers, the Protocol requires States which ratify it to take some steps to protect and assist trafficked persons. Trafficked persons would be entitled to confidentiality and have some protection against offenders, both in general and when they provide evidence or assistance to law enforcement agencies or appear as witnesses in prosecutions or similar proceedings. Some social benefits, such as housing, medical care and legal or other counselling are also provided for.

The legal status of trafficked persons and whether they would eventually be returned to their respective countries of origin has been the subject of extensive negotiations. Similar discussions have taken place with respect to the return of smuggled migrants in the Protocol dealing with them. Generally, developed countries to which persons are often trafficked have taken the position that there should not be a right to remain in their countries as this would provide an incentive both for trafficking and for illegal migration. Countries whose nationals were more likely to 
be trafficked wanted as much protection and legal status for trafficked persons as possible. The negotiations are still ongoing, but the text presently requires States "to consider" laws which would allow trafficked persons to remain, temporarily or permanently, "in appropriate cases" (Article 5). States would also agree to accept and facilitate the repatriation of their own nationals (Article 6).

\section{Part III - Prevention, Cooperation and other Measures (Articles 7 - 11)}

Generally, the law enforcement agencies of countries which ratify the Protocol would be required to cooperate in such matters as the identification of offenders and trafficked persons, sharing information about the method of offenders, and the training of investigators, enforcement and victim-support personnel (Article 7). Countries would also be required to implement security and border controls to detect and prevent trafficking. These include strengthening their own border controls, imposing requirements on commercial carriers to check passports and visas (Article 8), setting standards for the technical quality of passports and other travel documents (Article 9), and cooperation in establishing the validity of their own documents when used abroad (Article 6, para (3)). Cooperation between States who ratify is generally mandatory. Cooperation with States who are not parties to the Protocol is not required, but is encouraged (Article 11). Social methods of prevention, such as research, advertising, and social or economic support are also provided for, both by governments and in collaboration with non-governmental organizations (Article 10).

\section{(vi) General Comments}

Trafficking in women and children has no doubt become a global business generating huge profits for traffickers and organized crime syndicates. Out of the 15 to 30 million irregular migrants world-wide, 700,000 women and children are trafficked yearly across borders, numbers which are alarming. ${ }^{20}$

Out of the Fourth World Conference of Women held in Beijing, China, 1995 emerged a Platform of Action which acknowledged that "Human rights and fundamental freedoms are the birthright of all human beings; their protection and promotion is the first responsibility of governments". The Platform of Action also reaffirmed that all human rights - civil, cultural, economic, political and social, including the right to development, are universal, indivisible, interdependent and interrelated, as expressed in the Vienna Declaration and Programme of Action adopted by the World Conference of Human Rights. The Conference reaffirmed that the human rights of women and the girl-child are an inalienable, integral and indivisible part of universal human rights. The full and equal enjoyment of all human rights and fundamental freedoms by women and girls is a priority for Governments and the United Nations, and is essential in the advancement of women.

20 IOM counter-trafficking services: http//www.iom.int 
It is encouraging to note that most of the AALCO Member States are already parties to the Convention on the Elimination of all Forms of Discrimination Against Women, as well as the Convention on the Rights of the Child. This could help considerably in addressing these issues effectively and systematically throughout relevant bodies and mechanisms.

What is needed at this point is, as has rightly been mentioned in the explanatory note of the Government of Indonesia, the early ratification of the recent United Nations Convention Against Transnational Organized Crime and its Protocols, especially the Protocol to Prevent, Suppress and Punish Trafficking in Persons, especially in women and children, adopted by the United Nations General Assembly on 15 November 2000 and which will come into force after 40 countries have ratified it.

Another significant step for protection against trafficking in women and children could be the formulation of a model legislation, as suggested in the Indonesian proposal. This task could be accomplished with the technical assistance of the AALCO's new partner, the International Organization for Migration (IOM), with whom a Cooperation Agreement was signed on 6 October 2000. Of significant importance also would be more effective cooperation with the United Nations High Commissioner for Human Rights.

One of the programme activities of the AALCO Secretariat is to promote wider acceptance of International Conventions among the AALCO Member States. The preparation of a model legislation as a first step could facilitate the consideration by Member States of becoming Parties to the UN Convention Against Transnational Organized Crime, and its Protocols. Subsequently, the issues related to (a) the role of law enforcement in the trafficking in women and children; (b) prosecutorial strategies; (c) intelligence sharing, and (d) effective resources utilization and initiatives can be discussed. The Member States may wish to direct the Secretariat about the future course of action in this regard. 